\title{
Efisiensi Penggunaan Cahaya Matahari dan Partisi Karbohidrat Tanaman Sorgum pada Berbagai Tingkat Pemupukan Nitrogen
}

\author{
Light Use Efficiency and Carbohydrates Partitioning \\ of Sorghum on Various Level of Nitrogen Fertilizer
}

\author{
Firmansyah Aznur ${ }^{1}$, Suwarto $^{2 *}$, dan Heni Purnamawati ${ }^{2}$ \\ ${ }^{1}$ Program Studi Agronomi dan Hortikultura, Sekolah Pascasarjana, Institut Pertanian Bogor \\ ${ }^{2}$ Departemen Agronomi dan Hortikultura, Fakultas Pertanian, Institut Pertanian Bogor \\ (Bogor Agricultural University), Jl. Meranti, Kampus IPB Darmaga, Bogor 16680, Indonesia
}

Diterima 5 Desember 2016/Disetujui 24 Maret 2017

\begin{abstract}
Light use efficiency (LUE) determines biomass production based on interception energy during photosynthesis. The product of photosynthesis is allocated to the plants organs based on the partitioning of carbohydrates. The LUE and carbohydrate partitioning are two important parameters in crop modelling. The research was conducted at Cikabayan experimental station of IPB, Bogor from July to November 2015. The experiment was designed according to a randomize block design with five replications. The fertilizer treatments rate were $0 \%, 50 \%, 100 \%, 150 \%$, and $200 \%$ of reference $\mathrm{N}$ fertilization of $120 \mathrm{~kg} \mathrm{ha} a^{-1}$. The value of light use efficiency and the partition coefficient of sorghum were not affected by $N$ fertilization. The value of light use efficiency is $1.41 \mathrm{~g} \mathrm{MJ}^{1}$. The carbohydrates partitioning was developed based on plant growth stage. The partition from the planting to the emergence stage $(0 \leq s \leq 0.25)$ was $0.81 \times s / 0.25$ root, 0 stem, $0.19 x$ $s / 0.25$ leaves, and 0 panicle. The partition from the emergence to the maximum vegetative stage $(0.25<s \leq 0.5)$ was 0.81 $(0.59 \times \mathrm{s} / 0.5)$ root, $0.14 \times \mathrm{s} / 0.5 \mathrm{stem}, 0.19+(0.45 \times \mathrm{s} / 0.5)$ leaves, and 0 panicle. The partition from the maximum vegetative stage to the flowering stage $(0.5<s \leq 0.75)$ was $0.22-(0.09 \times \mathrm{s} / 0.75)$ root, $0.14+(0.39 \times \mathrm{s} / 0.75)$ stem, $0.64-(0.46 \times \mathrm{s} / 0.75)$ leaves, and $0.16 \times s / 0.75$ panicle. The partition from flowering to the harvest stage $(0.75<s \leq 1)$ was $0.13-(0.13 \times s)$ root, $0.53-(0.52 \times s)$ stem, $0.18-(0.18 \times s)$ leaves, and $0.16+(0.84 \times s)$ panicle.
\end{abstract}

Keywords: crop modelling, light use efficiency, $N$ fertilizer, partitioning carbohydrates

\section{ABSTRAK}

Efisiensi penggunaan cahaya (LUE) merupakan penentu produksi biomassa berdasarkan intersepsi energi pada proses fotosintesis. Hasil fotosisntesis dialokasikan menuju organ tanaman berdasarkan nilai partisi karbohidrat. LUE dan partisi karbohidrat adalah dua parameter penting dalam pemodelan tanaman. Penelitian dilakukan di kebun percobaan Cikabayan IPB, Bogor mulai bulan Juli sampai dengan November 2015. Percobaan menggunakan rancangan acak kelompok dengan lima ulangan. Perlakuan pemupukan N dengan dosis 0\%, 50\%, 100\%, 150\%, dan 200\% dari acuan pemupuka N sebesar 120 $\mathrm{kg} \mathrm{ha}{ }^{-1}$. Nilai LUE dan partisi karbohidrat tanaman sorgum tidak dipengaruhi oleh pemupukan N. Nilai LUE sorgum yaitu $1.41 \mathrm{~g} \mathrm{MJ}^{-1}$. Koefisien partisi karbohidrat ke organ tanaman merupakan fungsi dari fase perkembangan. Koefisien partisi mulai saat tanam sampai fase emergence $(0 \leq s \leq 0.25)$ adalah $0.81 \times s / 0.25 \mathrm{ke}$ akar, $0 \mathrm{ke}$ batang, $0.19 \times s / 0.25 \mathrm{ke}$ daun, dan 0 ke malai. Koefisien partisi mulai fase emergence sampai fase vegetatif maksimum $(0.25<s \leq 0.5)$ adalah $0.81-(0.59 \times s / 0.5)$ ke akar, $0.14 \times \mathrm{s} / 0.5 \mathrm{ke}$ batang, $0.19+(0.45 \times \mathrm{s} / 0.5) \mathrm{ke}$ daun, dan 0 ke malai. Koefisien partisi mulai fase vegetatif maksimum sampai fase bunga mekar $(0.5<s \leq 0.75)$ adalah $0.22-(0.09 \times \mathrm{s} / 0.75)$ ke akar, $0.14+(0.39 \times \mathrm{s} / 0.75)$ ke batang, $0.64-(0.46 x$ $s / 0.75)$ ke daun, dan $0.16 \times \mathrm{s} / 0.75 \mathrm{ke}$ malai. Koefisien partisi mulai fase bunga mekar sampai fase panen $(0.75<s \leq 1)$ adalah 0.13 - $(0.13 \times s)$ ke akar, $0.53-(0.53 \times s)$ ke batang, 0.18 - $(0.18 \times s)$ ke daun, dan $0.16+(0.84 \times s)$ ke malai.

Kata kunci: LUE, partisioning karbohidrat, pemupukan N, pemodelan tanaman

* Penulis untuk korespondensi. e-mail: wrtskm@yahoo.com 


\section{PENDAHULUAN}

Penduduk Indonesia pada tahun 2035 diproyeksi sebesar 305.6 juta jiwa, meningkat dari tahun 2010 sebesar 238.5 juta jiwa (BPS, 2015). Peningkatan penduduk akan meningkatkan kebutuhan pangan nasional. Salah satu cara untuk memenuhi kebutuhan adalah mengembangkan potensi pangan alternatif, diantaranya sorgum. Ruchjaniningsih (2009) menyatakan bahwa sorgum adalah bahan pangan yang karakteristik tepungnya relatif lebih baik dibanding tepung umbi-umbian. Sorgum memiliki kandungan protein, kalsium dan vitamin B1 yang lebih tinggi dibanding beras dan jagung sehingga potensial sebagai bahan pangan utama.

Sorgum memiliki daya adaptasi luas, baik di dataran rendah maupun dataran tinggi sehingga dapat dikembangkan di wilayah tropis (Human dan Sihono, 2010). Sorgum sebagai tanaman golongan $\mathrm{C} 4$ efisien dalam menghasilkan produk fotosintesis yang tinggi (Subagio dan Aqil, 2014). Sorgum toleran terhadap kekeringan dan genangan, sehingga mempunyai keunggulan dibandingkan komoditi lain untuk dikembangkan di lahan kering Indonesia (Sungkono et al., 2009). Biji sorgum digunakan sebagai bahan pangan serta bahan baku industri pakan dan industri gula. Kebutuhan sorgum beberapa tahun mendatang diperkirakan terus meningkat sejalan dengan bertambahnya jumlah penduduk. Oleh karena itu, usaha dalam meningkatkan produksi sorgum perlu dilakukan.

Peningkatan produksi sorgum dilakukan dengan mempelajari pertumbuhan dan produksi sorgum. Pertumbuhan dan produksi sorgum merupakan suatu sistem yang dipengaruhi banyak faktor. Penelitian agronomi untuk mengetahui pengaruh salah satu atau kombinasi faktor pertumbuhan hasilnya terbatas untuk waktu dan tempat tertentu sesuai dengan berlangsungnya penelitian, sehingga perlu penelitian ulang untuk diterapkan ditempat berbeda. Pemodelan (modelling) yang didefinisikan sebagai penyederhanaan suatu sistem dengan pendekatan mekanistik dapat dijadikan alternatif pendekatan untuk pemahaman proses ekofisiologis maupun prediksi pertumbuhan dan produksi tanaman (Qadir, 2012).

Efisiensi penggunaan cahaya (LUE) adalah salah satu peubah tetap dalam pemodelan tanaman. Pembengo et al. (2012) mengemukakan bahwa LUE merupakan komponen penentu pada pertumbuhan dan perkembangan tanaman yang dihubungkan dengan produksi akumulasi biomassa dari intersepsi energi. Produksi tanaman tergantung pada peran kanopi dalam mengintersepsi cahaya yang dipengaruhi oleh indeks luas daun (ILD) dan struktur kanopi. Kekurangan $\mathrm{N}$ dapat menurunkan nilai ILD sehingga terjadi penurunan intersepsi dan LUE (Salvagiotti dan Miralles, 2008). Nilai LUE berbeda untuk setiap tanaman. Monteith (1977) menjelaskan nilai LUE kebanyakan tanaman adalah $1.4 \mathrm{~g}$ $\mathrm{MJ}^{-1}$. Sebagai parameter perlu ditetapkan satu nilai LUE yang dapat mencerminkan pertumbuhan tanaman pada berbagai kondisi lingkungan.

Pertumbuhan tanaman ditentukan oleh prinsip aliran massa hasil fotosintesis ke organ tanaman (Fourcaud et al., 2008). Aliran massa energi produk fotosintesis yang dihasilkan dialokasikan menuju organ tanaman. Jumlah aliran massa yang masuk ke tiap organ, ditentukan oleh besarnya koefisien partisi (Qadir, 2012).

Nilai LUE dan partisi karbohidrat merupakan dua parameter penting dalam pemodelan pertumbuhan tanaman. Penelitian ini berguna untuk mengetahui nilai LUE dan partisi karbohidrat tanaman sorgum pada berbagai tingkat pemupukan N.

\section{BAHAN DAN METODE}

Penelitian dilakukan di kebun percobaan Cikabayan IPB, Bogor pada bulan Juli sampai dengan November 2015. Analisis tanah di laboratorium DITSL Fakultas Pertanian IPB. Bahan dan alat yang digunakan adalah benih sorgum varietas Numbu.

Penelitian menggunakan Rancangan Acak Kelompok yang terdiri atas lima perlakuan pemupukan $\mathrm{N}(0 \%, 50 \%$, $100 \%, 150 \%$, dan $200 \%$ dengan dosis acuan pemupukan $\mathrm{N} 120 \mathrm{~kg} \mathrm{~N} \mathrm{ha}^{-1}$ ) (Lumbantobing et al., 2008) dengan lima ulangan. Penanaman dilakukan dengan jarak tanam $75 \mathrm{~cm}$ x $25 \mathrm{~cm}$. Pupuk N diberikan sebelum tanam dan 4 minggu setelah tanam (mst) berupa pupuk urea dengan total sebesar $130.4 \mathrm{~kg} \mathrm{ha}^{-1}$ untuk perlakuan $50 \% \mathrm{~N}, 260.9 \mathrm{~kg} \mathrm{ha}^{-1}$ untuk perlakuan $100 \% \mathrm{~N}, 391.3 \mathrm{~kg} \mathrm{ha}^{-1}$ untuk perlakuan $150 \% \mathrm{~N}$, dan $521.7 \mathrm{~kg} \mathrm{ha}^{-1}$ untuk perlakuan $200 \%$ N. Pupuk lain yang diberikan diluar perlakuan adalah SP-36 sebesar $100 \mathrm{~kg} \mathrm{ha}^{-1}$ pada saat sebelum tanam, dan $\mathrm{KCl}$ sebesar $150 \mathrm{~kg} \mathrm{ha}^{-1}$ pada saat sebelum tanam dan 4 mst. Setiap lubang tanam ditanami 4 benih sorgum, dan dipertahankan 2 tanaman per lubang setelah tumbuh. Pemeliharaan tanaman dilakukan dengan pengendalian hama dan penyakit, penyiangan gulma, dan penyiraman sesuai kebutuhan tanaman. Pengamatan pada petakan $0.75 \mathrm{~m} \times 1.5 \mathrm{~m}$ sehingga didapatkan 12 tanaman contoh dari 6 lubang tanam yang dilakukan pada setiap fase perkembangan. Data dianalisis ragam dan diuji lanjut dengan Duncan multiple range test (DMRT) serta polinomial ortogonal.

Peubah perkembangan sorgum meliputi bobot kering organ tanaman (akar, batang, daun, malai, dan biji), indeks luas daun (ILD), intersepsi radiasi (Qint), efisiensi penggunaan cahaya (LUE), dan koefisien partisi diukur setiap fase perkembangan tanaman sorgum. Fase perkembangan tanaman sorgum terdiri atas fase emergence, vegetatif maksimum, bunga mekar, dan panen. Pengukuran tambahan juga dilakukan pada umur tanaman 10 hari dan 20 hari setelah fase emergence. Bobot kering tanaman dihitung dengan menimbang organ tanaman yang telah dipisahkan antara akar, batang, daun, malai, dan biji tanaman. Nilai ILD merupakan hasil perkalian antara bobot kering daun dan luas daun spesifik yang dihitung menggunakan Licor LI 3100. LUE dihitung berdasarkan rasio bobot kering tanaman yang dihasilkan selama periode waktu tertentu $(\triangle \mathrm{BK})$ terhadap jumlah energi radiasi yang diintersepsi (Qint) oleh tanaman. Apabila $\Delta \mathrm{BK} \leq 0$, diasumsikan tidak terjadi pertumbuhan dan LUE bernilai 0. Qint dihitung berdasarkan selisih radiasi yang datang di atas tajuk (Qs) dengan radiasi yang diteruskan dibawah tajuk (Q1) menggunakan alat Lutron LX 1108 . 


$$
\mathrm{LUE}=\frac{\Delta \mathrm{BK}}{\sum \text { Qint }}, \quad \text { Qint }=\mathrm{Qs}-\mathrm{Ql}
$$

Partisi $\left(\mathrm{p}_{\mathrm{i}}\right)$ dihitung berdasarkan rasio pertambahan bobot kering organ tanaman (akar, batang, daun, malai) pada fase perkembangan tertentu $\left(\mathrm{dBK}_{\mathrm{i}}\right)$ terhadap total pertambahan bobot kering tanaman pada fase perkembangan yang sama $\left(\mathrm{dBK}_{\text {total }}\right)$. Pertambahan bobot kering bernilai negatif diasumsikan tidak terjadi pertambahan bobot dan diberi nilai 0 .

$\mathrm{P}_{\mathrm{i}}=\frac{\mathrm{dBK}_{\mathrm{i}}}{\mathrm{dBK}_{\text {total }}}$

Koefisien partisi merupakan fungsi dari fase perkembangan (s) tanaman sorgum. Fase perkembangan dalam pemodelan sorgum dibedakan menjadi fase saat tanam $(\mathrm{s}=0)$, fase emergence $-\mathrm{em}(\mathrm{s}=0.25)$, vegetatif maksimumvm $(\mathrm{s}=0.50)$, bunga mekar-bm $(\mathrm{s}=0.75)$, dan panen-p $(\mathrm{s}=1)$. Pertambahan fase perkembangan $(\Delta \mathrm{s})$ dihitung berdasarkan rasio dari pengurangan suhu rata-rata harian (Tav) dan suhu dasar (To) sorgum dengan pertambahan unit panas (thermal unit-TU) dari tiap fase perkembangan (TUem, TUvm, TUbm dan TUp) sebagai berikut:

$$
\begin{aligned}
& \Delta \mathrm{s}=\frac{\text { Tav-To }}{\text { TUem }} ; \text { jika } 0 \leq \mathrm{s} \leq 0.25 \\
& \Delta \mathrm{s}=\frac{\text { Tav-To }}{\text { TUvm-TUem }} ; \text { jika } 0.25<\mathrm{s} \leq 0.5 \\
& \Delta s=\frac{\text { Tav-To }}{\text { TUbm-TUvm } ; \text { jika } 0.5<\mathrm{s} \leq 0.75} \\
& \Delta s=\frac{\text { Tav-To }}{\text { TUp-TUbm }} ; \text { jika } 0.75<\mathrm{s} \leq 1
\end{aligned}
$$

Suhu rata-rata harian (Tav) diperoleh dari Stasiun Klimatologi Darmaga Bogor. Suhu dasar (To) ditetapkan sebesar $15{ }^{\circ} \mathrm{C}$ (Singh dan Dhaliwal, 1972). TU dihitung berdasarkan hasil akumulasi dari selisih suhu rata-rata harian (Tav) terhadap suhu dasar (To) tanaman sorgum.

$$
\mathrm{TU}=\sum(\mathrm{Tav}-\mathrm{To})
$$

\section{HASIL DAN PEMBAHASAN}

\section{Efisiensi Penggunaan Cahaya}

Nilai efisiensi pengunaan cahaya (LUE) merupakan landaian (slope) dari hubungan antara Qint dengan akumulasi bahan kering ( $\triangle \mathrm{BK}$ total) yang dihasilkan selama periode emergence sampai panen (Maw et al., 2016; Houx dan Fritschi, 2015).

Perlakuan pemupukan $\mathrm{N}$ nyata mempengaruhi nilai bobot kering organ daun pada fase 10 hari setelah emergence, 20 hari setelah emergence, dan vegetatif maksimum. Bobot kering organ daun perlakuan N4 (150\% dosis $\mathrm{N}$ acuan) 0.64 $\mathrm{g} \mathrm{m}^{-1}$ dan N5 (200\% dosis N acuan) $1.00 \mathrm{~g} \mathrm{~m}^{-1}$ lebih tinggi dibandingkan perlakuan $\mathrm{N} 1(0 \%$ dosis $\mathrm{N}$ acuan $)$ dan $\mathrm{N} 2$ (50\% dosis $\mathrm{N}$ acuan) dengan nilai $0.39 \mathrm{~g} \mathrm{~m}^{-1}$ dan $0.46 \mathrm{~g}$ $\mathrm{m}^{-1}$ pada fase 10 hari setelah emergence, pola respon linear. Fase 20 hari setelah emergence perlakuan N4 (150\% dosis $\mathrm{N}$ acuan) dan $\mathrm{N} 5$ (200\% dosis $\mathrm{N}$ acuan) menghasilkan bobot kering organ daun $2.79 \mathrm{~g} \mathrm{~m}^{-1}$ dan $2.61 \mathrm{~g} \mathrm{~m}^{-1}$ lebih tinggi dibandingkan perlakuan $\mathrm{N} 1(0 \%$ dosis $\mathrm{N}$ acuan) dan $\mathrm{N} 2(50 \%$ dosis $\mathrm{N}$ acuan) dengan bobot kering organ daun $1.79 \mathrm{~g} \mathrm{~m}^{-1}$ dan $1.65 \mathrm{~g} \mathrm{~m}^{-1}$, pola respon linear. Fase vegetatif maksimum perlakuan $\mathrm{N} 3$ (100\% dosis $\mathrm{N}$ acuan), $\mathrm{N} 4(150 \%$ dosis $\mathrm{N}$ acuan) dan N5 (200\% dosis N acuan) menghasilkan bobot kering organ daun $65.91 \mathrm{~g} \mathrm{~m}^{-1}, 65.09 \mathrm{~g} \mathrm{~m}^{-1}$ dan 61.98 $\mathrm{g} \mathrm{m}^{-1}$ lebih tinggi dibandingkan perlakuan $\mathrm{N} 1(0 \%$ dosis $\mathrm{N}$ acuan) $42.37 \mathrm{~g} \mathrm{~m}^{-1}$, pola respon linear (Tabel 1).

Tabel 1 juga memperlihatkan fase 20 hari setelah emergence perlakuan $\mathrm{N} 4(150 \%$ dosis $\mathrm{N}$ acuan) dan $\mathrm{N} 5$ (200\% dosis $\mathrm{N}$ acuan) menghasilkan bobot kering total organ tanaman $5.42 \mathrm{~g} \mathrm{~m}^{-1}$ dan $5.40 \mathrm{~g} \mathrm{~m}^{-1}$ lebih tinggi dibandingkan perlakuan $\mathrm{N} 1(0 \%$ dosis $\mathrm{N}$ acuan) dan $\mathrm{N} 2(50 \%$ dosis $\mathrm{N}$ acuan) dengan bobot kering total organ tanaman $3.27 \mathrm{~g} \mathrm{~m}^{-1}$ dan $3.49 \mathrm{~g} \mathrm{~m}^{-1}$, pola respon linear. Fase vegetatif maksimum perlakuan $\mathrm{N} 3(100 \%$ dosis $\mathrm{N}$ acuan) dan $\mathrm{N} 4(150 \%$ dosis $\mathrm{N}$ acuan) menghasilkan bobot kering total organ $113.81 \mathrm{~g} \mathrm{~m}^{-1}$ dan $100.79 \mathrm{~g} \mathrm{~m}^{-1}$ lebih tinggi dibandingkan perlakuan N1 ( $0 \%$ dosis $\mathrm{N}$ acuan) dengan bobot kering total organ 64.92 $\mathrm{g} \mathrm{m}^{-1}$, pola respon linear. Pola respon linear menunjukkan peningkatan bobot kering tanaman dengan meningkatnya pemupukan N. Pemupukan N dapat meningkatkan hasil bobot kering tanaman (Maw et al., 2016; Anfinrud et al., 2013; Sawargaonkar et al., 2013).

Nilai intersepsi radiasi matahari (Qint) tergantung pada kemampuan tanaman dalam menyerap cahaya matahari. Kemampuan tanaman dalam menyerap cahaya matahari dipengaruhi oleh luas daun tanaman. Nilai indeks luas daun (ILD) sorgum pada Gambar 1 berkisar antara 0.02 hingga 1.81 . Nilai ILD terendah pada fase 10 hari setelah emergence dan tertinggi pada fase bunga mekar, setelah itu menurun karena terjadi pelayuan sebagian daun bagian bawah.

Nilai Qint tanaman sorgum berkisar $0.054 \mathrm{MJ} \mathrm{m}^{-2}$ hingga $11.04 \mathrm{MJ} \mathrm{m}^{-2}$. Nilai minimum dicapai pada fase emergence - 10 hari setelah emergence. Analisis ragam pada Tabel 2 menjelaskan perlakuan pemupukan $\mathrm{N}$ nyata mempengaruhi Qint pada fase emergence - 10 hari setelah emergence, fase 10 hari setelah emergence - 20 hari setelah emergence, dan fase 20 hari setelah emergence - vegetatif maksimum. Pemupukan N tidak mempengaruhi Qint pada fase vegetatif maksimum - bunga mekar dan fase bunga mekar - panen.

Uji lanjut Duncan pada Tabel 2 menjelaskan fase emergence - 10 hari setelah emergence perlakuan N5 (200\% dosis $\mathrm{N}$ acuan) setiap hari mengintersepsi radiasi cahaya matahari $0.070 \mathrm{MJ} \mathrm{m}^{-2}$ nyata lebih besar dibandingkan perlakuan $\mathrm{N} 1(0 \%$ dosis $\mathrm{N}$ acuan $)$ dan $\mathrm{N} 2(50 \%$ dosis $\mathrm{N}$ acuan) yang setiap hari mengintersepsi sebesar $0.054 \mathrm{MJ}$ $\mathrm{m}^{-2}$ dan $0.056 \mathrm{MJ} \mathrm{m}^{-2}$. Fase 10 hari setelah emergence - 20 hari setelah emergence perlakuan N3 (100\% dosis N acuan), N4 (150\% dosis N acuan), dan N5 (200\% dosis N acuan) setiap hari mengintersepsi radiasi cahaya matahari $0.25 \mathrm{MJ} \mathrm{m}^{-2}, 0.26 \mathrm{MJ} \mathrm{m}^{-2}$, dan $0.26 \mathrm{MJ} \mathrm{m}^{-2}$ nyata lebih besar dibandingkan perlakuan N1 ( $0 \%$ dosis $\mathrm{N}$ acuan) yang setiap hari mengintersepsi sebesar $0.19 \mathrm{MJ} \mathrm{m}^{-2}$. Fase 20 hari setelah emergence - vegetatif maksimum perlakuan N3 (100\% dosis N acuan) dan N4 (150\% dosis N acuan) 
Tabel 1. Bobot kering $\left(\mathrm{g} \mathrm{m}^{-1}\right)$ tanaman sorgum pada tingkat pemupukan $\mathrm{N}$ per fase perkembangan tanaman

\begin{tabular}{|c|c|c|c|c|c|c|c|}
\hline \multirow{2}{*}{$\begin{array}{l}\text { Bagian } \\
\text { tanaman }\end{array}$} & \multirow{2}{*}{ Pemupukan } & \multicolumn{6}{|c|}{ Fase perkembangan } \\
\hline & & $\mathrm{E}$ & $10 \mathrm{E}$ & $20 \mathrm{E}$ & VM & $\mathrm{BM}$ & Panen \\
\hline \multirow[t]{5}{*}{ Akar } & N1 & 0.24 & 0.43 & 1.07 & 14.92 & 82.63 & 60.73 \\
\hline & N2 & 0.27 & 0.34 & 1.44 & 15.50 & 81.51 & 49.56 \\
\hline & N3 & 0.28 & 0.40 & 1.62 & 28.87 & 90.05 & 81.61 \\
\hline & N4 & 0.26 & 0.40 & 1.89 & 22.42 & 79.97 & 103.72 \\
\hline & N5 & 0.26 & 0.35 & 2.23 & 19.47 & 91.24 & 75.50 \\
\hline \multicolumn{8}{|l|}{ Pola respon ${ }^{t}$} \\
\hline \multirow[t]{5}{*}{ Batang } & N1 & - & 0.20 & 0.42 & 7.63 & 264.20 & 206.51 \\
\hline & $\mathrm{N} 2$ & - & 0.24 & 0.39 & 8.55 & 239.90 & 211.08 \\
\hline & N3 & - & 0.19 & 0.51 & 19.03 & 314.26 & 295.58 \\
\hline & N4 & - & 0.20 & 0.74 & 13.28 & 301.35 & 262.06 \\
\hline & N5 & - & 0.22 & 0.55 & 14.99 & 271.18 & 174.49 \\
\hline \multicolumn{8}{|l|}{ Pola respon ${ }^{t}$} \\
\hline \multirow[t]{5}{*}{ Daun } & N1 & 0.06 & $0.39 d$ & $1.79 \mathrm{~b}$ & $42.37 b$ & 139.85 & 77.02 \\
\hline & $\mathrm{N} 2$ & 0.06 & $0.46 \mathrm{~cd}$ & $1.65 b$ & $50.50 \mathrm{ab}$ & 140.37 & 72.48 \\
\hline & N3 & 0.06 & $0.62 b c$ & $2.05 \mathrm{ab}$ & $65.91 \mathrm{a}$ & 157.39 & 77.53 \\
\hline & N4 & 0.07 & $0.64 \mathrm{ab}$ & $2.79 \mathrm{a}$ & $65.09 \mathrm{a}$ & 156.04 & 98.98 \\
\hline & N5 & 0.06 & $1.00 \mathrm{a}$ & $2.61 \mathrm{a}$ & $61.98 \mathrm{a}$ & 160.95 & 81.24 \\
\hline Pola respon $^{t}$ & & & $\mathrm{~L}^{*}$ & $\mathrm{~L}^{* *}$ & $\mathrm{~L}^{* *}$ & & \\
\hline \multirow[t]{5}{*}{ Malai } & N1 & - & - & - & - & 74.66 & 208.97 \\
\hline & $\mathrm{N} 2$ & - & - & - & - & 79.83 & 258.97 \\
\hline & N3 & - & - & - & - & 80.69 & 260.2 \\
\hline & N4 & - & - & - & - & 80.04 & 293.55 \\
\hline & N5 & - & - & - & - & 77.55 & 192.12 \\
\hline \multicolumn{8}{|l|}{ Pola respon ${ }^{t}$} \\
\hline \multirow[t]{5}{*}{ Biji } & N1 & - & - & - & - & - & 168.95 \\
\hline & $\mathrm{N} 2$ & - & - & - & - & - & 213.40 \\
\hline & N3 & - & - & - & - & - & 214.11 \\
\hline & N4 & - & - & - & - & - & 241.64 \\
\hline & N5 & - & - & - & - & - & 152.25 \\
\hline \multicolumn{8}{|l|}{ Pola respon $^{t}$} \\
\hline \multirow[t]{5}{*}{ Total } & N1 & 0.31 & 1.03 & $3.27 \mathrm{~b}$ & $064.92 b$ & 561.34 & 553.23 \\
\hline & $\mathrm{N} 2$ & 0.32 & 1.04 & $3.49 \mathrm{~b}$ & $074.55 \mathrm{ab}$ & 541.62 & 592.09 \\
\hline & N3 & 0.34 & 1.21 & $4.18 \mathrm{ab}$ & $113.81 \mathrm{a}$ & 642.39 & 714.92 \\
\hline & N4 & 0.32 & 1.23 & $5.42 \mathrm{a}$ & $100.79 a$ & 617.41 & 758.30 \\
\hline & N5 & 0.32 & 1.57 & $5.40 \mathrm{a}$ & $096.44 \mathrm{ab}$ & 600.92 & 523.34 \\
\hline Pola respon ${ }^{t}$ & & & & $\mathrm{~L}^{* *}$ & $\mathrm{~L}^{* *}$ & & \\
\hline
\end{tabular}

Keterangan: Angka yang diikuti huruf yang sama pada kolom dan bagian yang sama menunjukkan hasil yang tidak berbeda nyata berdasarkan DMRT pada $\alpha=5 \% ; \mathrm{t}=$ uji polinomial ortogonal terhadap dosis pupuk; $\mathrm{L}=$ linier; $*$ nyata taraf $5 \%$; ** = nyata taraf $1 \% ; \mathrm{E}=$ emergence $; 10 \mathrm{E}=10$ hari setelah emergence $; 20 \mathrm{E}=20$ hari setelah emergence $; \mathrm{VM}=$ vegetatif maksimum; $\mathrm{BM}=$ bunga mekar

setiap hari mengintersepsi radiasi cahaya matahari 3.37 $\mathrm{MJ} \mathrm{m}^{-2}$ dan $3.43 \mathrm{MJ} \mathrm{m}^{-2}$ nyata lebih besar dibandingkan perlakuan $\mathrm{N} 1(0 \%$ dosis $\mathrm{N}$ acuan) dan $\mathrm{N} 2(50 \%$ dosis $\mathrm{N}$ acuan) yang setiap hari mengintersepsi sebesar $2.26 \mathrm{MJ} \mathrm{m}^{-2}$ dan 2.70 $\mathrm{MJ} \mathrm{m}^{-2}$. Penambahan dosis pupuk N 0-200\% dari acuan menunjukkan pola respon linear terhadap nilai Qint pada fase emergence - 10 hari setelah emergence, 10 hari setelah fase emergence - 20 hari setelah emergence, dan 10 


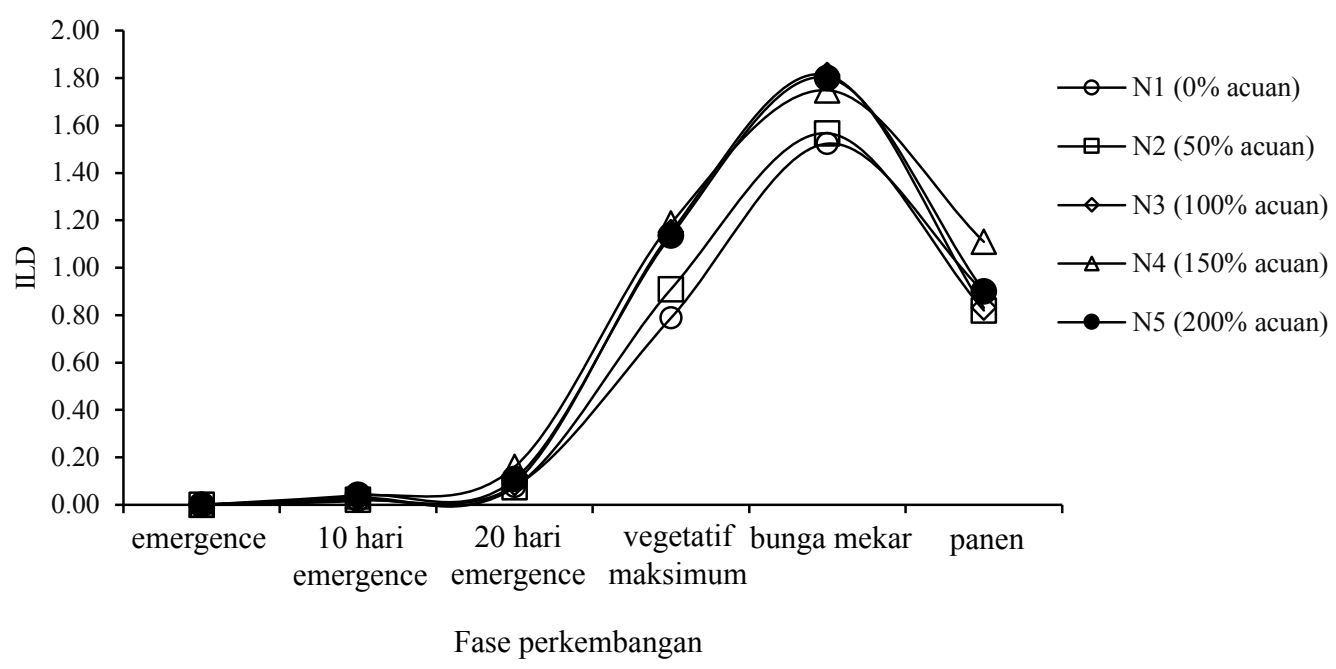

Gambar 1. Nilai ILD pada tingkat pemupukan N per fase perkembangan sorgum

Tabel 2. Nilai intersepsi radiasi (Qint) $\left(\mathrm{MJ} \mathrm{m}^{-2}\right)$ harian sorgum pada tingkat pemupukan N per fase perkembangan tanaman

\begin{tabular}{lcccccc}
\hline \multirow{2}{*}{ Pemupukan } & \multicolumn{5}{c}{ Fase perkembangan } \\
\cline { 2 - 7 } & $\mathrm{E}$ & $\mathrm{E}-10 \mathrm{E}$ & $10 \mathrm{E}-20 \mathrm{E}$ & $20 \mathrm{E}-\mathrm{VM}$ & VM-BM & BM-Panen \\
\hline N1 & 0 & $0.054 \mathrm{~b}$ & $0.19 \mathrm{~b}$ & $2.26 \mathrm{~b}$ & 10.51 & 6.83 \\
N2 & 0 & $0.056 \mathrm{~b}$ & $0.20 \mathrm{ab}$ & $2.70 \mathrm{~b}$ & 10.37 & 6.48 \\
N3 & 0 & $0.065 \mathrm{ab}$ & $0.25 \mathrm{a}$ & $3.37 \mathrm{a}$ & 10.97 & 6.32 \\
N4 & 0 & $0.065 \mathrm{ab}$ & $0.26 \mathrm{a}$ & $3.43 \mathrm{a}$ & 11.04 & 6.68 \\
N5 & 0 & $0.070 \mathrm{a}$ & $0.26 \mathrm{a}$ & $3.21 \mathrm{ab}$ & 10.88 & 7.66 \\
Pola respon $^{t}$ & & $\mathrm{~L}^{* *}$ & $\mathrm{~L}^{* *}$ & $\mathrm{~L}^{* *}$ & tn & tn \\
\hline
\end{tabular}

Keterangan: Angka yang diikuti huruf yang sama pada kolom yang sama menunjukkan hasil yang tidak berbeda nyata berdasarkan DMRT pada $\alpha=5 \% ; \mathrm{t}=$ uji polinomial ortogonal terhadap dosis pupuk; $\mathrm{Q}=$ kuadratik; $\mathrm{L}=$ linier $=*=$ nyata taraf $5 \% ; * *=$ nyata taraf $1 \% ; \mathrm{E}=$ emergence $; 10 \mathrm{E}=10$ hari setelah emergence $; 20 \mathrm{E}=20$ hari setelah emergence $; \mathrm{VM}=$ vegetatif maksimum; $\mathrm{BM}=$ bunga mekar

hari setelah fase emergence - vegetatif maksimum. Giunta et al. (2009) menyatakan $\mathrm{N}$ yang diserap tanaman membentuk pola yang linear terhadap nilai Qint.

Hasil analisis diperoleh nilai LUE berkisar antara 1.34 $\mathrm{g} \mathrm{MJ}^{-1}$ sampai $1.49 \mathrm{~g} \mathrm{MJ}^{-1}$ (Tabel 3), nilai ini sejalan dengan hasil penelitian Kiniry et al. (1989) yang melaporkan nilai LUE jagung sebesar $1.6 \mathrm{~g} \mathrm{MJ}^{-1}, 1.3 \mathrm{~g} \mathrm{MJ}^{-1}$ untuk sorgum dan bunga matahari, serta $1.0 \mathrm{~g} \mathrm{MJ}^{-1}$ untuk padi dan gandum. Pemupukan $\mathrm{N}$ tidak mempengaruhi nilai LUE, sehingga nilai LUE yang digunakan sebagai input model adalah rata-

Tabel 3. Nilai efisiensi penggunaan cahaya matahari $\left(\mathrm{g} \mathrm{MJ}^{-1}\right)$ sorgum pada tingkat pemupukan $\mathrm{N}$ per fase perkembangan tanaman

\begin{tabular}{|c|c|c|c|c|c|c|}
\hline \multirow{2}{*}{ Pemupukan } & \multicolumn{5}{|c|}{ Fase perkembangan } & \multirow{2}{*}{$\begin{array}{c}\text { LUE } \\
\text { E-Panen }\end{array}$} \\
\hline & E-10E & $10 \mathrm{E}-20 \mathrm{E}$ & $20 \mathrm{E}-\mathrm{VM}$ & VM-BM & BM-Panen & \\
\hline N1 & 1.31 & 1.21 & 0.64 & 2.61 & 1.19 & 1.39 \\
\hline $\mathrm{N} 2$ & 1.27 & 1.22 & 0.64 & 2.5 & 1.10 & 1.34 \\
\hline N3 & 1.36 & 1.22 & 0.77 & 2.68 & 0.97 & 1.40 \\
\hline N4 & 1.39 & 1.56 & 0.64 & 2.62 & 0.94 & 1.43 \\
\hline N5 & 1.74 & 1.46 & 0.65 & 2.58 & 1.00 & 1.49 \\
\hline Rata-rata & - & - & - & - & - & $\overline{\mathrm{LUE}}=1.41$ \\
\hline
\end{tabular}

Keterangan: E: emergence, 10E: 10 hari setelah emergence, 20E: 20 hari setelah emergence, VM: vegetatif maksimum, BM: bunga mekar, LUE: efisiensi penggunaan cahaya 
rata dari total nilai LUE sebesar $1.41 \mathrm{~g} \mathrm{MJ}^{-1}$. Nilai minimum LUE dicapai pada fase emergence dan nilai maksimum pada fase bunga mekar. Peningkatan nilai LUE dan Qint dari fase emergence menuju fase bunga mekar, serta penurunan nilai LUE pada fase panen merupakan hasil dari perubahan nilai ILD dari tiap fase perkembangan. Muurinen dan Sainio (2006) menyatakan bahwa nilai LUE meningkat sejalan dengan meningkatnya nilai ILD.

\section{Koefisien Partisi}

Alokasi biomassa tanaman menunjukkan pentingnya rasio biomassa tanaman terhadap biomassa total tanaman (Mathieu et al., 2009). Partisi untuk fase emergence adalah $81 \%$ ke akar, $0 \%$ ke batang, $19 \%$ ke daun, dan $0 \%$ ke malai. Partisi untuk fase vegetatif maksimum adalah $22 \%$ ke akar, 14\% ke batang, 64\% ke daun, dan 0\% ke malai. Partisi untuk fase bunga mekar adalah 13\% ke akar, 53\% ke batang, $18 \%$ ke daun, dan $16 \%$ ke malai. Partisi untuk fase panen adalah $0 \%$ ke akar, $0 \%$ ke batang, $0 \%$ ke daun, dan $100 \%$ ke malai (Tabel 4). Peningkatan bobot kering tanaman oleh penambahan pemupukan nitrogen pada Tabel 1 tidak mempengaruhi nilai partisi tanaman sorgum.
Koefisien partisi biomassa hasil fotosintesis ke organ merupakan fungsi dari fase perkembangan (s). Pertambahan fase perkembangan $(\Delta s)$ sorgum dihitung berdasarkan konsep thermal unit (TU). Nilai thermal unit dari saat tanam sampai fase emergence (TUem) adalah $53{ }^{\circ} \mathrm{C}$, dari fase emergence sampai fase vegetatif maksimum (TUvm) adalah $764.5^{\circ} \mathrm{C}$, dari fase vegetatif maksimum sampai fase bunga mekar (TUbm) adalah $974{ }^{\circ} \mathrm{C}$, dari fase bunga mekar sampai fase panen (TUp) adalah $1219^{\circ} \mathrm{C}$.

Berdasarkan data partisi biomasa pada Tabel 4, koefisien partisi pada pemodelan sorgum dapat ditetapkan sebagai berikut; mulai saat tanam sampai fase emergence $(0$ $\leq \mathrm{s} \leq 0.25$ ) adalah $0.81 \times \mathrm{s} / 0.25 \mathrm{ke}$ akar, 0 ke batang, $0.19 \mathrm{x}$ $\mathrm{s} / 0.25$ ke daun, dan 0 ke malai. Mulai fase emergence sampai fase vegetatif maksimum $(0.25<\mathrm{s} \leq 0.5)$ adalah $0.81-(0.59$ $\mathrm{x} \mathrm{s} / 0.5)$ ke akar, $0.14 \mathrm{x} \mathrm{s} / 0.5 \mathrm{ke}$ batang, $0.19+(0.45 \mathrm{x} \mathrm{s} / 0.5)$ ke daun, dan 0 ke malai. Mulai fase vegetatif maksimum sampai fase bunga mekar $(0.5<\mathrm{s} \leq 0.75)$ adalah $0.22-(0.09$ $\mathrm{x} \mathrm{s} / 0.75)$ ke akar, $0.14+(0.39 \times \mathrm{s} / 0.75)$ ke batang, $0.64-$ $(0.46 \times$ s s/0.75) ke daun, dan 0.16 x s/0.75 ke malai. Mulai fase bunga mekar sampai fase panen $(0.75<\mathrm{s} \leq 1)$ adalah 0.13 - $(0.13 \times \mathrm{s})$ ke akar, $0.53-(0.53 \times \mathrm{s}) \mathrm{ke}$ batang, 0.18 $(0.18 \times \mathrm{s})$ ke daun, dan $0.16+(0.84 \times \mathrm{s})$ ke malai (Tabel 5).

Tabel 4. Partisi tanaman sorgum per fase perkembangan tanaman

\begin{tabular}{lcccc}
\hline \multirow{2}{*}{ Bagian tanaman } & \multicolumn{4}{c}{ Fase perkembangan } \\
\cline { 2 - 5 } & Emergence & Vegetatif maksimum & Bunga mekar & Panen \\
\hline Akar & 0.81 & 0.22 & 0.13 & 0.00 \\
Batang & 0.00 & 0.14 & 0.53 & 0.00 \\
Daun & 0.19 & 0.64 & 0.18 & 0.00 \\
Malai & 0.00 & 0.00 & 0.16 & 1.00 \\
\hline
\end{tabular}

Tabel 5. Koefisien partisi tanaman sorgum per fase perkembangan tanaman

\begin{tabular}{lll}
\hline Bagian tanaman & \multicolumn{1}{c}{ Fase perkembangan } & \multicolumn{1}{c}{ Koefisien partisi } \\
\hline Akar & Tanam - Emergence $; \mathrm{s} \leq 0.25$ & $0.81 \times \mathrm{s} / 0.25$ \\
& Emergence - Veg. Maksimum $; 0.25<\mathrm{s} \leq 0.5$ & $0.81-(0.59 \times \mathrm{s} / 0.5)$ \\
& Veg. maksimum - Bunga mekar $; 0.5<\mathrm{s} \leq 0.75$ & $0.22-(0.09 \times \mathrm{s} / 0.75)$ \\
& Bunga mekar - Panen $; 0.75<\mathrm{s} \leq 1$ & $0.13-(0.13 \times \mathrm{s})$ \\
\hline Batang & Tanam - Emergence $; \mathrm{s} \leq 0.25$ & 0 \\
& Emergence - Veg. Maksimum $; 0.25<\mathrm{s} \leq 0.5$ & $0.14 \times \mathrm{s} / 0.5$ \\
& Veg. maksimum - Bunga mekar $; 0.5<\mathrm{s} \leq 0.75$ & $0.14+(0.39 \times \mathrm{s} / 0.75)$ \\
& Bunga mekar - Panen $; 0.75<\mathrm{s} \leq 1$ & $0.53-(0.53 \times \mathrm{s})$ \\
\hline Daun & Tanam - Emergence $; \mathrm{s} \leq 0.25$ & $0.19 \times \mathrm{s} / 0.25$ \\
& Emergence - Veg. Maksimum $; 0.25<\mathrm{s} \leq 0.5$ & $0.19+(0.45 \times \mathrm{s} / 0.5)$ \\
& Veg. maksimum - Bunga mekar $; 0.5<\mathrm{s} \leq 0.75$ & $0.64-(0.46 \times \mathrm{s} / 0.75)$ \\
& Bunga mekar - Panen $; 0.75<\mathrm{s} \leq 1$ & $0.18-(0.18 \times \mathrm{s})$ \\
\hline Malai & Tanam - Emergence $; \mathrm{s} \leq 0.25$ & 0 \\
& Emergence - Veg. Maksimum $; 0.25<\mathrm{s} \leq 0.5$ & 0 \\
& Veg. maksimum - Bunga mekar $; 0.5<\mathrm{s} \leq 0.75$ & $0.16 \times \mathrm{s} / 0.75$ \\
& Bunga mekar - Panen $; 0.75<\mathrm{s} \leq 1$ & $0.16+(0.84 \times \mathrm{s})$
\end{tabular}

Keterangan: $\mathrm{s}=$ fase perkembangan tanaman 


\section{KESIMPULAN}

Peningkatan pemupukan nitrogen (N) tidak mempengaruhi nilai LUE dan koefisien partisi tanaman sorgum, namun berpengaruh pada bobot kering daun pada 10 hari dan 20 hari setelah emergence dan fase vegetatif maksimum, serta bobot kering total tanaman pada 20 hari setelah emergence dan fase vegetatif maksimum. Nilai LUE tanaman sorgum sebesar $1.41 \mathrm{~g} \mathrm{MJ}^{-1}$ dapat digunakan sebagai parameter dalam pemodelan tanaman sorgum.

\section{DAFTAR PUSTAKA}

Anfinrud, R., L. Cihacek, B.L. Johnson, Y. Ji, M.T. Berti. 2013. Shorgum and kenaf biomass yield and quality response to nitrogen fertilization in the Northern Great Plains of the USA. Ind. Crops Prod. 50:159165.

[BPS] Badan Pusat Statistik. 2015. Proyeksi jumlah penduduk Indonesia sampai tahun 2035 dan data produksi padi nasional 2010-2014. http://www.bps. go.id [1 Februari 2015].

Fourcaud, T., X. Zhang, A. Stokes, H. Lambers, C. Komer. 2008. Plant growth modelling and application: The increasing importance of plant architecture in growth models. Ann. Bot. 101:1053-1063

Giunta, F., G. Pruneddu, R. Motzo. 2009. Radiation interception and biomass nitrogen accumulation in different cereal and grain legume spesies. Field Crops Res. 110:76-84.

Houx, J.H.III., F.B. Fritschi. 2015. Influence of late planting on light interception, radiation use efficiency and biomass production of four sweet sorghum cultivars. Ind. Crops Prod. 76:62-68.

Human, S., Sihono. 2010. Sorghum breeding for improved drought tolerance using induced mutation with gamma irradiation. J. Agron. Indonesia 38:95-99.

Kiniry, J.R., C.A. Jones, O'Toole, R. Blanchet, M. Cabelguene, D.A. Spanel. 1989. Radiation use efficiency in biomass accumulation prior to grain filling for five grain-crop species. Field Crops Res. 20:51-64.

Lumbantobing, E.L.N., F. Hazra, I. Anas. 2008. Uji efektifitas bio-organic fertilizer (pupuk organik hayati) dalam mensubtitusi kebutuhan pupuk anorganik pada tanaman sweet sorgum. J. Tanah Lingkungan 10:7276.

Mathieu, A., P.H. Cournede, V. Letort, D. Barthelemy, P. de Reffye. 2009. A dynamic model of plant growth with interaction between development and functional mechanism to study plant structural plasticity related to tropic competition. Ann. Bot. 103:1173-1186.

Maw, M.J.W., Houx, J.H.III., F.B. Fritschi. 2016. Sweet sorghum ethanol yield component response to nitrogen fertilization. Ind. Crops Prod. 84:43-49.

Monteith, J.L. 1977. Climate and the efficiency of crop production in Britain. Philos. Trans. R. Soc. London. Ser. B. 281:277-294.

Muurinen, S., P.P. Sainio. 2006. Radiation-use efficiency of modern and old spring cereal cultivars and its response to nitrogen in northern growing conditions. Field Crops Res. 96:363-373.

Pembengo, W., Handoko, Suwarto. 2012. Efisiensi penggunaan cahaya matahari oleh tanaman tebu pada berbagai tingkat pemupukan nitrogen dan fosfor. J. Agron. Indonesia 40:211-217.

Qadir, A. 2012. Pemodelan pertumbuhan tanaman kedelai (Glycine $\max$ (L.) Merrill) di bawah cekaman naungan. Tesis. Sekolah Pascasarjana. Institut Pertanian Bogor. Bogor.

Ruchjaniningsih. 2009. Rejuvenasi dan karakterisasi morfologi 225 Aksesi Sorgum. hal. 77-81. Dalam Maros (Eds.). Prosiding Seminar Nasional Serelia. Sulawesi Selatan 29 Juli 2009.

Salvagiotti, F., D.J. Miralles. 2008. Radiation interception, biomass production and grain yield as affected by the interaction of nitrogen and sulfur fertilization in wheat. Eur. J. Agron. 28:282-290.

Sawargaonkar, G.L., M.D. Patil, S.P. Wani, E. Pavani, B.V.S.R. Reddy, S. Marimuthu. 2013. Nitrogen response and water use efficiency of sweet sorghum cultivars. Field Crops Res. 149:245-251.

Singh, N.T., G.S. Dhaliwal. 1972. Effect of soil temperature and seedling emergence in different crops. Plant Soil 37:441-444.

Subagio, H., M. Aqil. 2014. Perakitan dan pengembangan varietas unggul sorgum untuk pangan, pakan, dan bioenergi. Iptek Tanaman Pangan 9:39-50.

Sungkono, Trikoesoemaningtyas, D. Wirnas, D. Sopandie, S. Human, M.A. Yudiarto. 2009. Pendugaan parameter genetik dan seleksi galur mutan sorgum (Sorghum bicolor (L.) Moench) di tanah masam. J. Agron. Indonesia 37:220-225. 